\title{
Research on Integration Mechanism of High-end Manufacturing Industry and High-end Service Industry
}

\author{
Jun Xu, Xingcheng Ge \\ Business School, Jiangsu Normal University, Xuzhou 221116,China \\ Corresponding author e-mail:Immxjxj@163.com
}

\begin{abstract}
At present, the global industrial structure begins to shift from industrial economy to service-oriented economy, and gradually develop high-end service industry into an important pillar industry of a country. Due to the relationship between high-end service industry and high-end manufacturing industry, they have developed a trend to integrate mutually. This paper tries to analyze the connotation of high-end manufacturing industry and high-end service industry, and then discusses the integration mechanism between high-end manufacturing industry and high-end service industry. Finally, we put forward the suggestions to promote the integration and development of the two.
\end{abstract}

\section{Introduction}

Since 1980s, the development of the new technology revolution has changed the global industrial structure, and began to change from the industrial economy to the service economy. With the rapid development of information network, the relationship and industrialization between high-end manufacturing industry and high-end service industry has been continuously strengthened ${ }^{[1]}$. At the same time, the boundary between high-end manufacturing industry and high-end service industry has become blurred to some extent, which shows that the two promote each other and present the trend of integration development. This promotes the development of new industrialization. In recent years, although China's high-end manufacturing industry have made significant achievements in many areas, low technology content, low added value of products and low value chain are still the problems that restrict the development of high-end manufacturing industry in China. Therefore, under this background, the development and progress of high-end manufacturing industry not only depends on its own continuous efforts, but also depends on the promotion and development of related industries. The high-end service industry, which has the characteristics of high specialization, intensive knowledge, and high technology and so on, contributes more and more to the economic development. The innovation and development of technology as well as the upgrading of the manufacturing industry have produced extremely strong radiation effects. High-end service industry can interact with high-end manufacturing industry through $\mathrm{R} \& \mathrm{D}$, production, sales, consulting and many other key links, and play a "propeller" role in the development of high-end manufacturing industry ${ }^{[2]}$.Therefore, it is valuable to study the interactive integration of high-end manufacturing and high-end services. 


\section{The interaction connotation between high-end manufacturing industry and high-end service industry}

\subsection{Integration and development of spatial layout}

High-end service industry is a knowledge-based and technology-intensive industry, which can promote the upgrading and transformation of the manufacturing industry, while the high-end manufacturing industry often shows a more obvious spatial agglomeration in the process of continuous development. It is usually gathered in various industrial parks. With the development of science and technology, the industrial agglomeration of high-end manufacturing industry is gradually increasing, and the demand for high-end service industry is also increasing, which promotes the further development of high-end service industry. Due to the increasing demand of high-end manufacturing industry for high knowledge and technology content of high-end service industry, it can promote the spatial agglomeration of high-end manufacturing industry through the agglomeration development of high-end service industry.

\subsection{The co-evolution of development model}

The co-evolution of high-end manufacturing industry and high-end service industry is mainly reflected in two aspects: evolution foundation and evolution model. The coordinated development of the external environment of high-end manufacturing and high-end service industry is the basis of the evolution of the integration of the two industries, that is to say, the co-evolution of high-end manufacturing industry and high-end service industry needs relevant policies and market environment to coordinate and improve, thus breaking down the barriers between industries, institutions and regions, and promoting the integration and development of the two. In the process of coordinated development of financial industry and high-end manufacturing industry, the development of high-end manufacturing industry needs a lot of capital investment, but also needs the strong support of the financial industry. But the financial industry has a "threshold effect" on corporate credit, that is, those high-income, high-efficiency large-scale high-end manufacturing industry is more likely to be strongly supported by the financial industry. And some small high-end manufacturing industry is difficult to raise the funds needed for development, which has created an obstacle to the integration of high-end manufacturing and high-end services.

\subsection{Industrial innovation coordination}

The highest stage of the integration development of high-end manufacturing industry and high-end service industry is to realize the optimal dynamic development of both and to realize the optimization and upgrading of their industrial structure. At this stage, integration innovation is the driving force to optimize high-end manufacturing and high-end service systems. Through integration innovation, high-end service industry can provide more advanced elements for high-end manufacturing industry, and choose the best integration path for the dynamic evolution of high-end manufacturing industry and high-end service industry through continuous optimization of elements. 


\section{The integration mechanism between high-end manufacturing industry and high-end service industry}

\subsection{High-end service industry promotes the development of high-end manufacturing industry}

3.1.1 High-end service industry promotes the transformation of high-end manufacturing industry to service-oriented manufacturing

"Made in China 2025" pointed out that the future development of China's manufacturing industry, to high-end, intelligent, green, service-oriented transformation. Service-oriented high-end manufacturing industry has developed into an important source of efficiency and innovation in high-end manufacturing industry. Service manufacturing has become the most potential business direction in high-end manufacturing industry. On the one hand, the service of high-end manufacturing industry can reduce the pollution to the environment, get rid of the input of resources and energy and at the same time, it can better meet the needs of users and improve the comprehensive competitiveness of the industry. On the other hand, the development of high-end service industry promotes the upgrading of high-end manufacturing industry to service-oriented enterprises.

3.1.2Optimizing resource allocation of high-end manufacturing industry in high-end service industry High-end service industry not only promotes high-end manufacturing industry to save energy and reduce environmental pollution, but also improves the utilization rate of resources. High-end service industry belongs to information technology-intensive industry. The application of information technology and the development of science and technology service industry promote the development of high-end service industry itself. It has also become a major driving force for high-end manufacturing industry to save resources and energy and reduce environmental pollution. The improvement and upgrading of enterprise infrastructure and the continuous optimization of production mode have strengthened the monitoring of resource consumption and promoted the development of industry towards low consumption and high efficiency ${ }^{[4]}$.

3.1.3 High-end service industry reducing production cost and transaction cost of high-end manufacturing industry

Firstly, the scale effect of high-end services will reduce the production costs of high-end manufacturing. With the deepening of the division of labor, those low value-added production links within the high-end manufacturing industry will gradually become externalized, and eventually separated from the high-end manufacturing industry into an independent production sector ${ }^{[5]}$. And it can provide specialized high-end services, its development scale will be expanded with the increase of external demand, and eventually form a certain scale economy. This greatly reduces the production cost of the high-end manufacturing industry compared with the high-end services within the high-end manufacturing industry.

Secondly, in the market allocation of service products, high-end service industry can play a role in simplifying the transaction mode, thus reducing the transaction cost of service products in high-end manufacturing enterprises. For example, traffic, communication and other circulation services in high-end services industry can connect the spatio-temporal segmentation of the market by establishing a market network system, and expand the scope and scale of the market. It can reduce transaction costs under the role of economies of scale. 


\subsection{High-end manufacturing promoting the development of high-end service industry}

\subsubsection{High-end manufacturing providing a solid market base for high-end services}

Under the background of deepening social division of labor, the externalization of production in high-end manufacturing promotes the development of high-end service industry and makes it have sufficient market resources and firm demand basis. With the development of economy, the high-end manufacturing industry will more and more outsource the production links with lower added value in order to reduce the production and transaction costs and improve the comprehensive competitiveness, making the "non-market activities" of "internalization" gradually become "market activities" of "externalization". At this time, with the increase of outsourcing of high-end manufacturing enterprises, the outside of those specialized high-end service enterprises will produce a large number of market demands. This provides sufficient market resources and firm demand basis for the development of high-end services. In addition, the development of high-end manufacturing industry will also have new requirements for the type and quantity of service outsourcing, which to some extent promotes the high-end service enterprises to constantly improve their service types and service quality. It also provides a driving force for the development of high-end services.

3.2.2 Information technology accelerating the role of high-end manufacturing industry in promoting high-end service industry

Firstly, the high-end service industry as an intermediate input activity, its service is to provide the final product or service of the productive enterprises. High-end service industry as an information technology-intensive industry, the rapid development of information technology has promoted the continuous upgrading of high-end services, which can effectively improve the work efficiency and service quality of high-end service enterprises. In addition, with the continuous development of the traditional service industry, new high-end service areas will be derived, such as computer-aided manufacturing and computer-integrated manufacturing. The development of high-end manufacturing industry will provide a large amount of market demand for high-end services, which greatly enhances the transaction of high-end services.

Secondly, the development of information technology not only promotes the upgrading of high-end manufacturing industry, but also provides a more complete infrastructure for the development of high-end service industry. For example, the development of information technology makes the information technology content of high-end manufacturing enterprises much higher, which provides a reliable platform for logistics enterprises in the supply chain. So that the regional transfer of industrial clusters and the reasonable arrangement of industrial distribution can be realized. In addition, information technology and the corresponding communications, transportation and other infrastructure has gradually become the support platform for the development and upgrading of the service industry. Among high-end service industries, financial services, logistics, transportation and other industries on transport, communications and other infrastructure dependence is becoming more and more obvious.

\section{The integration suggestions between high-end manufacturing industry and high-end service industry}

4.1 Building a platform for the coordinated development of high-end service industry and high-end manufacturing industry and promoting institutional cooperation 
In recent years, many aspects of practice have proved that a key point of the integration of high-end manufacturing and high-end services is the establishment of an efficient basic platform, thus forming a supporting system for the integration and development of the two. At present, there are still no convenient communication channels between manufacturing industry and service industry in many areas, which makes the information between supply and demand cannot be exchanged and feedback in time. As a result, some manufacturing enterprises choose to provide their own services because they do not meet the existing external services ${ }^{[6]}$. So, the service-oriented enterprises are difficult to develop because of insufficient demand. Therefore, service-oriented enterprises need to speed up the construction of high-end service public information platform, establish an effective information sharing mechanism, so that the manufacturing industry and the service industry can timely exchange and feedback information. At the same time, we should speed up the construction of multi-party communication platform to improve the efficiency of the use of information resources. In addition, in the process of integration of high-end manufacturing and high-end services, there are institutional mechanisms and policy constraints. Therefore, government departments at all levels should take the initiative to coordinate regional policies according to local conditions, actively explore the institutional mechanism for the integration and development of high-end manufacturing and high-end services, and establish a standardized market system. We should increase the introduction of high-end talents, funds and advanced technologies, create an integrated system and policy environment, and form an external environment conducive to the integration and development of the two. At the same time, it is also necessary to introduce policies conducive to the integration of high-end manufacturing and high-end services to promote the integration of the development of the two.

\subsection{Promoting the coordinated development of high-end service industry and high-end manufacturing} industry by developing information technology, building a networked industrial ecosystem.

Information technology not only promotes the development of high-end manufacturing industry and high-end service industry, but also provides an advanced technology platform for the interaction between them. This will help to solve some institutional and technical problems in the process of integration and development. Therefore, we should further enhance the level of information technology services, promote the coordinated development of information industry and high-end manufacturing industry, and increase the development of information technology outsourcing and business process outsourcing. Through the integration of information technology service institutions and technical resources, we can mobilize research and development, intermediary services and other specialized technical forces, establish high-end manufacturing and high-end services network collaboration platform and characteristic industry alliance etc. To achieve a close link between high-end manufacturing and high-end services, we can accelerate the development of service-oriented manufacturing, and improve the level of integration of high-end manufacturing and high-end services. Eventually, we establish the integrated development of the industrial ecosystem of the two ${ }^{[7]}$.

\subsection{Developing and implementing policies that encourage the integration of high-end services and} high-end manufacturing industries

The innovation between high-end manufacturing industry and high-end service industry is closely coordinated, so we should change the single industrial innovation policy into collaborative innovation 
policy. High-end manufacturing industry has the characteristics of high specialization, strong learning ability, and fast innovation and so on, while the high-end service industry, on the contrary, has a low degree of specialization and learning ability. This hinders their collaborative innovation. But the practice shows that the high-end manufacturing industry is not sensitive to the system change, while the high-end service industry is very sensitive. Therefore, in order to promote the integration of high-end manufacturing and high-end service innovation, enterprises should focus on the adjustment of high-end services in policy design. In the specific implementation measures, we should increase the reform of the high-end service sector, increase investment in high-end services. At the same time, we should make use of our own development advantages and favorable conditions to open wider to the outside world, actively attract foreign investment and high-end talents into high-end services, and create more favorable conditions for the internationalization of high-end services. While developing high-end manufacturing industry, we should consider comprehensively according to the actual situation in various places, and develop high-end manufacturing industry in line with local advantages and development plans. Through the rational tilt of policy, it can realize the integration of high-end manufacturing and high-end services innovation.

\section{Conclusion}

At present, the global industrial structure has begun to change, gradually from the industrial economy to the service-oriented economy, and the service industry has developed into an important pillar industry of a country. This makes the development of high-end manufacturing and high-end services also gradually showing the trend of integration and development. Our country attaches great importance to the integration of high-end manufacturing and high-end services, and lists them as the main driving industries of the national economy. In addition, the relevant government departments have also issued a number of policies to promote the interaction and development of the two.

Firstly, this paper tries to define the connotation of high-end manufacturing industry and high-end service industry, and classify them in detail. Then it discusses the integration mechanism between high-end manufacturing industry and high-end service industry, in order to provide a new perspective for the interaction and integration of the two issues. Eventually it puts forward some policy recommendations on the development of the integration of the two.

\section{References}

[1] Jiao Aili: Business Time, (2014) No.17,p.123-124.

[2] Hu Jing: Financial Research,(2015) No.2, p.1-3.

[3] Liu Yang: Productivity Research,Vol.35 (2011) No.3, p.92-94.

[4] Gao Qingyu: Strategic Research on constructing Highland of High-end Manufacturing Industry in Tianjin(MS., Tianjin: Tianjin University, China 2010).

[5] Cao Dongpo, Yu Cheng, Xu Baochang: Economic and Management Studies,(2014) No.3, p .76-86.

[6] Li Changying, Zhang Lihong: Technology and Industry, Vol15, (2015) No.12, p.43-45.

[7] Yang Yuxiu: Economic Outlook the BoHai Sea,(2016) No.9, p.6-9. 